\title{
JUDICIAL REVIEW OF RULEMAKING: NEW PATTERNS AND NEW PROBLEMS*
}

\author{
FREDERICK DAVIS $* *$
}

The principles that govern judicial power in reviewing challenged administrative rules have never been fully resolved or established. ${ }^{1}$ Recent regulatory statutes, particularly the post- 1970 pollution control efforts, ${ }^{2}$ display differences and contradictions regarding the availability and scope of judicial review that have taxed the analytical capacities of scholars, ${ }^{3}$ lawyers, ${ }^{4}$ and judges. ${ }^{5}$ This article discusses the various statutory patterns of rulemaking review and concludes that the regulatory legislation reflects five distimct patterns. Once these patterns are identified and described, it is possible to explore and appraise the serious problems that confront judges called upon to review rules adopted under legislation that requires judicial review pursuant to one of these five patterns. The article focuses on statutes providing for pre-enforce-

* This article is based on a report prepared for the Administrative Conference of the United States. The views expressed herein are those of the author and are not necessarily those of the Administrative Conference.

* Dean, University of Dayton School of Law. A.B. 1948, Yale University; J.D. with specialization in international affairs 1953, Cornell University; LL.M. 1955, Victoria University of Wellington (N.Z.). Meniber, New York and Missouri Bars.

1. For an illuminating analysis of the policies and practical considerations bearing upon the roles of agencies and courts in the ruleinaking process, see DeLong, Informal Rulemaking and the Integration of Law and Policy, 65 VA. L. Rev. 257 (1979). For insightful discussions of the problems directly related to judicial review of agency mulemaking, sce Verkuil, Judicial Review of Informal Rulemaking, 60 VA. L. REv. 185 (1974); Note, Judicial Review of Agency Rule Making, 14 GA. L. Rev. 300 (1980).

2. See, e.g., Federal Water Pollution Control Act, 33 U.S.C. $\$ 1369$ (1976); Noise Control Act of 1972, 42 U.S.C. \$ 4915 (1976); Sohd Waste Disposal Act, 42 U.S.C. § 6976 (1976); Clean Air Act Amendnents of 1977, 42 U.S.C. $\$ 7607$ (Supp. II 1978).

3. See, e.g., Auerbach, Informal Rulemaking: A Proposed Relationship, 72 Nw. U.L. REv. 15, 26-30 (1977); Currie, Judicial Review Under Federal Pollution Laws, 62 IowA L. REV. 1221 (1977).

4. Consider the solution Judge McGowan proposed for the perplexed attorneys in Investment Co. Inst. v. Board of Governors of Fed. Reserve Sys., 551 F.2d 1270, 1280 (D.C. Cir. 1977):

If any doubt as to the proper forum exists, careful counsel should file suit in both the court of appeals and the district court. . . . This suggestion is hardly unprecedented; the plaintiffs im Whitney National Bank v. Bank of New Orleans, [379 U.S. 411 (1965),] . . . were able to protect their rights by following the double-filing procedure.

5. See, e.g., Adamo Wrecking Co. v. United States, 434 U.S. 275 (1978); E.I. du Pont de Nemours \& Co. v. Train, 430 U.S. 112 (1977); Investunent Co. Inst. v. Board of Governors of Fed. Reserve Sys., 551 F.2d 1270 (D.C. Cir. 1977). 
ment review of rules and the problems these statutes create concerning the availability of additional review im enforcement proceedings. ${ }^{6}$

The current problems and concerns about the judicial role in reviewing federal administrative rules are, to a great extent, related to the watershed case of Abbott Laboratories v. Gardner. ${ }^{7}$ In that case the Supreme Court endorsed the presumption of reviewability of agency action, absent " 'clear and convincing evidence' of a contrary legislative intent."" 8 The Court also held that pre-enforcement judicial review of administrative rules was to be available if the challenging party could make a showing of conspicuous hardship. ${ }^{9}$ This holding made review available to many challenges previously denied review on the ground that the action was not ripe for review. By accepting the idea that preenforcement judicial review of administrative rules is neither aberrant nor unauthorized, the Abbott Laboratories Court paved the way for the widespread statutory use of pre-enforcement judicial review, and for the creation of the different modes of statutory review with which this article is concerned. ${ }^{10}$

\section{Patterns of Statutes Governing Review of ADMINISTRATIVE RULES}

A close study of the legislation governing rulemaking review reveals that there are five patterns of statutes: ${ }^{11}$

6. No attempt is made here to coordinate the scope and intensity of judicial review with the procedural qualities of the rulemaking process that generated the rules. This difficult problem is addressed in two thought-provoking and thoroughly developed articles by Professor Daniel Gifford. Gifford, Rulemaking and Rulemaking Review: Struggling Toward a New Paradigm, 32 ADMIN. L. REV. 577 (1980); Gifford, Administrative Rulemaking and Judicial Review: Some Conceptual Models, 65 MINN. L. REv. 63 (1980).

7. 387 U.S. 136 (1967). The case is soinetimes referred to as the "every time case" because the inajor rules at issue required pharmaceutical manufacturers to print the generic name of a drug every time the trade naine of the drug appeared on the manufacturers' labels or other printed material. Id. at 138-39.

8. Id. at 141 .

9. Id. at 153-54.

10. Significantly, this statutory trend came only in the wake of the Abbott Laboratories decision. See Appendix, infra. The majority opimion appears not to have foreseen this development. Even Mr. Justice Fortas's lengthy and prophetic dissent, which emphasized the disruptive effect that pre-enforcement review can have on a vital regulatory program, does not deal with the forum choice coinplexities and other einbarrassments that can result froin permitting different modes of review at different points in time. 387 U.S. at 174-201 (Fortas, J., dissenting). Those who cominented on the case also failed to anticipate the congressional response. See The Supreme Court, 1966 Term, 81 Harv. L. Rev. 110, 225-31 (1967); 52 MINN. L. Rev. 872 (1968).

11. See Appendix, infra, for a selected list of statutes by category. 
(1) Legislation that confers rulemaking power on the agency but makes no provision for or reference to judicial review; 12

(2) Legislation that provides for judicial review in federal district court but establishes no time limit within which review must be sought; ${ }^{13}$

(3) Legislation that provides for direct pre-enforcement review within a prescribed time period after promulgation and explicitly preserves the jurisdiction of the appropriate court to review the validity of regulations after the prescribed period in enforcement proceedings; ${ }^{14}$

(4) Legislation that provides for direct pre-enforcement review within a prescribed time period following promulgation but is silent about the availability of review in enforcement proceedings or otherwise; ${ }^{15}$ and

(5) Legislation that provides for direct pre-enforcement review within a prescribed time period and prohibits, except under limited conditions, review of the rule in an enforcement proceeding. ${ }^{16}$

Pattern 1 is quite common, and does not involve serious problems regarding the appropriate forum or form of proceeding for review. ${ }^{17}$ Congressional silence on the procedures for judicial review automatically invokes the non-statutory review procedures analyzed in the $A b$ bott Laboratories case. ${ }^{18}$ This first type of rule is reviewable in the

12. See, e.g., 5 U.S.C. $\$ 1302$ (Supp. II 1978) (conferring power on the Office of Personnel Management to prescribe and enforce various types of regulations for the administration of the provisions of Title 5, but making no mention of any special judicial review procedures); 12 U.S.C. $\$ 1902$ (1976) (conferring rulemaking power upon the Board of Governors of the Federal Reserve System under the National Credit Union Central Liquidity Facihty Act); 42 U.S.C. $\$ 1302$ (1976) (conferring rulemaking authority on the Secretaries of Labor, Health and Human Services, and the Treasury to "make and publish such rules and regulations as nuay be necessary for the efficient administration of the functions with which each is charged under this chapter").

13. See, e.g., Department of Energy Organization Act, 42 U.S.C. \& 7192(g) (Supp. II 1978) (conferring power upon the district courts of the United States to resolve cases or controversies arising "under rules, regulations, or orders" issued by the Federal Energy Regulatory Commission).

14. See, e.g., Magnuson-Moss Warranty-Federal Trade Commission Improvement Act, 15 U.S.C. § 57a(e) (1976); Toxic Substances Control Act, 15 U.S.C. \& 2618 (1976).

15. The pre-enforcement review may be in the court of appeals or in the district court. The most notable of the legislative provisions imposing court-of-appeals review within a prescribed time period is the Admimistrative Orders Review Act, 28 U.S.C. $\$ \$ 2341-2353$ (1976), as amended by Hobbs Act, 28 U.S.C. $\S 2342$ (Supp. II 1978). The Marine Maminal Protection Act, 16 U.S.C. $\S 1374(d)(6)$ (1976), provides for pre-enforcement review in the district courts.

16. E.g., Federal Mine Safety and Health Amendments Act, 30 U.S.C. § 811(d) (Supp. II 1978), and statutes cited in note 2 supra.

17. K. Davis, Administrative LaW: Cases-Text-Problems 171 (6th ed. 1977).

18. Abbott Laboratories v, Gardner, 387 U.S. 136, 139 (1966). 
district court. ${ }^{19}$ Injunction and declaratory judgment, the traditional non-statutory forms of judicial review, are the appropriate methods of review for such rules. ${ }^{20}$ Recent decisions have considered the issues of the availability and timing of review in classification (1) cases by focusing on how substantial the administrative pronouncement's impact is upon a particular person or a discrete class of persons. ${ }^{21}$

In a typical pattern 2 statute, Congress provides for district court review of rules but imposes no time limits or other special conditions varying the conditions of review. ${ }^{22}$ Pattern 2 thus differs from pattern 1 only in that in limited situations there may be some doubt about the reviewability of a rule promulgated under a pattern 1 statute. If Congress has declared the rules subject to judicial review, as it does under those situations covered by classification (2), the ambiguity disappears.

In pattern 3 statutes, Congress explicitly provides for both pre-enforcement review of rules and review as part of enforcement proceedings. Thus, pattern 3 statutes do not present serious questions about the availability of review. They do, however, differ from statutes in patterns 4 and 5, which provide for pre-enforcement review but either say nothing about the availability of additional review or purport to foreclose such review. We now turn to the problems created by these statutes.

\section{Problems Arising from Congressional Prescription of a Limited TIMe PERIOd For Judicial Review of Rules}

\section{A. Pattern 4: A Prescribed Time Period is Established for Pre- enforcement Review, but the Statute is Silent about Review in Enforcement Proceedings.}

Statutes that provide a specific procedure for pre-enforcement review within a prescribed time period, without indicating whether that procedure is exclusive, put interpretative responsibilities of considerable complexity upon the federal judiciary. Under these circumstances courts have held either that the normal rules governing judicial review in enforcement proceedings and in other proceedings outside the prescribed time period still apply; ${ }^{23}$ or that, by implication, review outside

19. W. Gellhorn, C. Byse \& P. Strauss, Administrative law: Cases and Comments 921 (7th ed. 1979).

20. K. Davis, Administrative Law Text $444-46$ (3d ed. 1972).

21. See, e.g., Diamond Shamrock Corp. v. Costle, 580 F.2d 670 (D.C. Cir. 1978); Bethlehem Steel Corp. v. EPA, 536 F.2d 156 (7th Cir. 1976).

22. See, e.g., Department of Energy Organization Act, 42 U.S.C. $\$ 7192$ (Supp. II 1978).

23. See, e.g., Deering Milliken, Inc. v. OSHRC, 630 F.2d 1094 (5th Cir. 1980); United States v. McCrillis, 200 F.2d 884 (1st Cir. 1952); Smith v. United States, 199 F.2d 377 (1st Cir. 1952). 
the prescribed pre-enforcement time period is barred; ${ }^{24}$ or that review outside the time period is available but more restricted than usual. ${ }^{25}$

City of Rochester v. Bond ${ }^{26}$ illustrates the view that a statute providimg only for pre-enforcement review bars additional review. The case mvolved review of the Federal Aviation Administration's determination that a proposed six-hundred-foot radio antenna tower near an airport would not be a hazard. The Rochester City Council, instead of seeking review within sixty days in the Court of Appeals for the District of Columbia Circuit, ${ }^{27}$ filed suit nine months later in district court to have the agency's determination set aside. The district court dismissed the suit and the court of appeals affirmed the dismissal, holding:

Congress acting within its constitutional powers, may freely choose the court in which judicial review may occur. In the absence of a statute prescribing review in a particular court, "non-statutory" review may be sought in district court under any applicable jurisdictional grant. If, however, there exists a special statutory review procedure, it is ordinarily supposed that Congress intended that procedure to be the exclusive means of obtaining judicial review in those cases to which it applies. ${ }^{28}$

The court stated that additional review procedures might be available in exceptional circumstances but did not find such circumstances present in the case at bar. ${ }^{29}$

Atlantic \& Gulf Stevedores v. Occupational Safety \& Health Review Commission $^{30}$ and National Industrial Constructors v. Occupational

24. See, e.g., Whitney Nat'l Bank v. New Orleans Bank, 379 U.S. 411 , 425 (1965); United States v. Bodine Produce Co., 206 F. Supp. 201, 204 (D. Ariz. 1962).

25. E.g., Byrd v. United States, 154 F.2d 62, 64 (5th Cir. 1946) (when limited judicial review is available, a rule may be collaterally attacked in a condemnation proceeding only upon constitutional grounds).

26. 603 F.2d 927 (D.C. Cir. 1979).

27. The order was reviewable under both the Communications Act, 47 U.S.C. $\S 402$ (c) (1976) (30 days), and the Aviation Act, 49 U.S.C. $\$ 1486$ (a) (1976) (60 days).

28. 603 F.2d at 931 .

29. Id. at 935-39. This exception, which resembles exceptions to the exhaustion-ofadministrative-rcmedies doctrine and the final-order doctrine, suggests that the Bond court's holding rests on principles of judicial administration rather than on statutory interpretation. See generally FTC v. Standard Oil Co., 101 S. Ct. 488 (1980) (denying review); Leedoin v. Kyne, 358 U.S. 184 (1958) (granting review). Additional review might be deemed unavailable in classification (4) cases as a matter of Congressional intent since Congress did not expressly provide for additional review as it did in classification (3) statutes. This construction would follow from a literal application of the so-called "expressio unius" rule, but the Supreme Court has not been inclined to give a literal enforcement of that rule in other contexts. See, e.g., Scripps-Howard Radio, Inc. v. FCC, 316 U.S. 4 (1942). Application of the rule in interpreting these statutes is particularly inappropriate because of the existence of statutes expressly providing review in enforcement proceedings (classification (3)) as well as statutes expressly forbidding review outside of pre-enforcement proceedings (classification (5)).

30. 534 F.2d 541 (3d Cir. 1976). 
Safety \& Health Review Commission ${ }^{31}$ held that the substantive validity of Occupational Safety and Health Administration regulations can be challenged in an enforcennent action. Challenges to the procedures used in adopting the regulation, however, will be allowed only during pre-enforcement review. ${ }^{32}$

The substantive-procedural distinction drawn in National Industrial Constructors and Atlantic \& Gulf Stevedores has a surface logic. A purely technical shortcoming in the process of proinulgation should not be the basis for setting aside an otherwise legitimate regulatory prograin authorized by Congress. The time for dealing with such deficiencies is during the period of pre-enforcement review. Yet the distinction between substantive and procedural matters may be slippery. ${ }^{33}$ The failure to coinply with a procedural requirement might result in the promulgation of a rule whose substantive validity is so questionable that an appellant, clearly aggrieved by the application of the rule in an enforcement proceeding, ought to be permitted to raise it even though Congress had provided for pre-enforcement judicial review during a prescribed period.

This problein is illustrated by United States v. Nova Scotia Food Products Corp. ${ }^{34}$ In that case the Food and Drug Administration promulgated, without making available for notice and cominent the scientific data it relied on, regulations governing the proper time, temperature, and sahnity for the process of smoking fish. ${ }^{35}$ Five years later the agency brought an enforcement proceeding against Nova Scotia, which contended that whitefish processed in conformity with the regulation would be commercially unsalable. The Court of Appeals for the Third Circuit declared the regulation imvalid. The court accepted the company's argument that the agency's failure to disclose the scientific

31. 583 F.2d 1048 (8th Cir. 1978).

32. Id. at 1052-53; 534 F.2d at 55I-52. But see Deering Milliken, Inc. v. OSHRC, $630 \mathrm{~F} .2 \mathrm{~d}$ 1094, 1098-99 (5th Cir. 1980). Although the Atlantic Gulf Stevedores opinion is phrased in terms of burden of proof, the result is that the petitioner may not rely on mere procedural irregularities in the promulgation of the regulatiou without establishing an aggrieving substantive effect. 534 F.2d at 551-52.

33. See Mr. Justice Frankfurter's classic description of the substantive-procedural distinction in Guaranty Trust Co. v. York, 326 U.S. 99, 108 (1945) and questions raised in P. BAToR, P. Mishkin, D. Shapiro, \& H. Wechsler, Hart \& Wechsler's The Federal Courts aNd the FeDERAL SYSTEM 728-29 (2d ed. 1973).

34. 568 F.2d 240 (2d Cir. 1977). The statute in Nova Scotia did not explicitly provide for preenforcement review but the liberal non-statutory pre-enforcement review authorized by $A b b o t t$ Laboratories made the rule eligible for virtually the same pre-enforcement review. Thus, the court likely would have reached the same result had the case involved a true classification (4) statute.

35. 34 Fed. Reg. 17,176 (1969). 
data it relied on rendered impossible any effective criticism of the methodology and interpretation of the data. ${ }^{36}$

The holding of Nova Scotia suggests that when the procedural deficiency appears so substantial that it raises doubts about the substantive validity of the rule, and the objector can point to significant aggrievement directly related thereto, the courts should allow the objeetor to challenge the validity of the rule despite the deficiency's procedural character and despite the lapse of a significant period of time after promulgation of the rule. ${ }^{37}$

\section{B. Pattern 5: A Specific Time Period is Prescribed by Statute for Pre- enforcement Review with a Prohibition against Enforcement \\ Review Outside that Time Period except under Limited Conditions.}

Pattern 5, which explicitly cuts off the availability of review, is the most controversial of the classifications under consideration. Variations of the formula appear in at least five statutes, including tlie Clean Air Act Amendments of $1977^{38}$ and the Federal Water Pollution Control Act. ${ }^{39}$ These five statutes provide for pre-enforcement review, usually in the Court of Appeals for the District of Columbia Circuit, within sixty or ninety days after pronulgation of the regulation in question. ${ }^{40}$ After that period the regulation is generally incontestable.

36. $568 \mathrm{~F} .2 \mathrm{~d}$ at 251 .

37. The key criteria that affect the availability of judicial review outside the limited period of pre-enforcement review are similar to those considerations that determine whether an objector to administrative action should be excused from complying with the exhaustion-of-administrativeremedies rule-namely, (1) degree of aggrievement; (2) degree of facial illegahty; and (3) nonembarrassment of the regulatory goals as a result of the judicial review. See Lone Star Cement Corp. v. FTC, 339 F.2d 505, 510 (9th Cir. 1964); K. Davis, 3 Administrative Law Treatise 69 (1958).

38. 42 U.S.C. $\$ 7607$ (Supp. II 1978).

39. 33 U.S.C. $\S 1369$ (1976). See also Federal Mine Safety and Health Amendments Act, 30 U.S.C. § 811 (Supp. II 1978); Noise Control Act, 42 U.S.C. § 4915 (1976); Solid Waste Disposal Act, 42 U.S.C. $§ 6976$ (1976); Federal Aviation Act, 49 U.S.C. $§ 1431$ (1976), as amended, (Supp. II 1978).

40. Deciding when the rule has been promulgated for purposes of defining the pre-enforcement review period has presented difficult construction problems. For example, in Independent Cosmetic Mfrs. v. Department of HEW, 574 F.2d 553 (D.C. Cir. 1978), the petitioner did not file its petition for review within the ninety-day period following the initial promulgation of the contested rule-an FDA labeling regulation. The petitioner argued, however, that the possibility of further amendments from the suggestions of other parties prevented an immediate determination of the rule's impact. Thus, the review period should have commenced sometime after the initial promulgation of the rule. The court nevertheless held the petition barred. Id. at 559. Judge Wilkey filed a twenty-two page dissent in which he argued that the ninety-day period should not have begun before the date the agency responded to objections made to the regulation as originally promulgated. Before that date, according to Judge Wilkey, the petitioner could not determine that it would be adversely affected by the regulation. Any judicial challenge it made prior to 
Four of the statutes contain a single exception allowing review if the petition for review is based on grounds arising after the pre-enforceinent review period.41 The goal of these statutes is to minimize the delays and uncertainties in the administrative implennentation of pollution control programs that can result from the numerous and geographically diversified judicial challenges. The constitutionality of the particular review provisions, however, is not free froln doubt.

The current pattern 5 statutes are modeled after a controversial World War II act sharply limiting the opportunity of aggrieved persons to challenge judicially the validity of regulations issued pursuant to the Eniergency Price Control Act. ${ }^{42}$ The Supreine Court upheld the review-limitimg provisions against a due-process challenge in Yakus v. United States. ${ }^{43}$ As long as the statute provided "an adequate opportumity to be heard on the question of vahidity," 44 which the Court found it did through pre-enforceinent review, the preclusion of challenges in enforceinent proceedings was permissible. ${ }^{45}$ Justice Rutledge argued in dissent that to prevent challenges to the validity of regulations would give the regulations a greater immunity from judicial review than the

that date, therefore, would be found unripe for review. Id. at 580. For other cases involving the question of when a rule is promulgated, see Laminators Safety Glass Ass'n v. Consumer Prod. Safety Comm'n, 578 F.2d 406, 409 (D.C. Cir. 1978); Industrial Union Dep't v. Bimgham, 570 F.2d 965, 968-69 (D.C. Cir. 1977).

41. Water Pollution Control Act, 33 U.S.C. $\S 1369(b)(1)$ (1976); Noise Control Act, 42 U.S.C. § 4915(a) (1976); Solid Waste Disposal Act, 42 U.S.C. \& 6976(1) (1976); Clean Air Act Amendments of 1977, 42 U.S.C. $\$ 7607$ (b)(1) (Supp. II 1978). This limiting phrase seems to have been taken from a World War II statute limiting the grounds upon which price and rent control regulations might be attacked. See Emergency Price Control Act of 1942, Pub. L. No. 77-421, 56 Stat. 23, 31-33 (1942) (amended 1944).

To fall under the exception, the imperfection arising after the expiration of the time period must be one that would have been considered disabling during the prescriptive period of preenforcement review. Union Elec. Co. v. EPA, 427 U.S. 246, 255-56 (1976). In other words, when Congress authorized judicial review in enforcement proceedings of rules based upon grounds arising after the prescriptive period had expired, it did not intend to enlarge the scope of review beyond that given to the courts during the period of pre-enforcement review. At least one court of appeals has held that the imperfection arising after the expiration of the prescriptive period of review must be based upon teclinological or scientific developments, not on changes in the law. See American Ass'n of Meat Processors, v. Costle, 556 F.2d 875, 877 (8th Cir. 1977).

42. The Emergency Price Control Act of 1942, $\S \S 203$ (a), 204(d), Pub. L. No. 77-421, 56 Stat. 23, 31-33 (1942) (amended 1944). The Act created an Emergency Court of Appeals with cxclusive jurisdiction to hear appeals of challenges to the validity of the regulations. Persons objectimg to a regulation were required to file a protest with the Price Administrator within sixty days after the regulation was issued and appeal to the Emergency Court within thirty days after the denial of the protest.

43. 321 U.S. 414 (1944).

44. Id. at 446.

45. Id. The Court reserved the question of whether facial unconstitutionality of a regulation could be asserted in an enforcement proceeding. Id. at 446-47. 
statutes under which they were promulgated:46 "At a time when administrative action assumes more and more of the law-making function, it would seem the balance of advantage, if any, should be the other way. . . . Clearly Congress could not require judicial enforcement of an unconstitutional statute. The same is true of an unconstitutional regulation." 47

Courts presented with cases questioning the contmumg validity of Yakus have avoided the issue, primarily by characterizing the administrative pronouncement or action being challenged as outside the statutory authority granting immunity from challenges. In Adamo Wrecking Co. v. United States ${ }^{48}$ the challenged statute granted Environmental Protection Agency (EPA) emission standards immunity from review in enforcement proceedings. ${ }^{49}$ The EPA promulgated a rule requiring buildings to be sprayed with water before demolition. When the wrecking company challenged the rule in an enforceinent proceeding, the Supreme Court held that the rule was a "work-practice standard" and not an "emission standard." 50 The rule was therefore not eligible for the imcontestable status the statute conferred upon emission standards. Justice Powell wrote a short concurring opmion in which he speculated that, had the Court reached the question of the validity of the incontestability clause, it might have limited Yakus by viewing the Emergency Price Control Act as an exercise of congressional war powers. Under such a view, Justice Powell believed, the EPA incontestability clause would have been struck down. ${ }^{51}$

In Chrysler Corp. v. EPA ${ }^{52}$ the Court of Appeals for the District of Colunbia Circuit interpreted narrowly the special statutory review procedure of the Noise Control Act of 1972,53 to avoid foreclosing en-

\footnotetext{
46. Id. at 468-69 (Rutledge, J., dissenting).

47. Id. at 469 (Rutledge, J., dissenting).

48. 434 U.S. 275 (1978).

49. 42 U.S.C. $\& 7607$ (Supp. II 1978).

50. 434 U.S. at 289.

51. Although the opinion of Mr. Chief Justice Stone is not free from ambiguity, there is language emphasizing that the price controls imposed by the Congress were a "war emergency measure." Indeed, the Government argued that the statute should be upheld under the war powers authority of Congress. . . . As iniportant as environmental concerns are to the country, they are not comparable-in terms of an emergency justifying the shortcutting of normal due process rights-to the need for national mobilization in wartime of economic as well as military activity. ... Indeed, following Yakus, and apparently concemed by Mr. Justice Rutledge's eloquent dissent, Congress amended the most onerous features of the Emergency Price Control Act.
}

Id. at 290-91 (Powell, J., concurring). Professor David Currie anticipated Justice Powell's opmion in a 1977 law review article criticizing the application of the Yakus rule in environmental cases. Currie, supra note 3 , at 1259.

52. 600 F.2d 904 (D.C. Cir. 1979).

53. 42 U.S.C. $\$ 4915$ (1976). 
forcement review of a large number of rules.54 The court noted the possible unfairness of foreclosing review, the recommendation of the Administrative Conference of the United States that mvalidity be a defense im an enforcement proceeding, ${ }^{55}$ and Justice Powell's suggestion that due process might not justify imcontestability outside a wartime setting. 56

Should a case arise in which it is clear that Congress has foreclosed review, the Supreme Court will not be able to avoid deciding the delicate constitutional issue that the review-denial language of the statute poses. Whether the rule-mcontestability provisions of the current environmental statutes satisfy due process inust be decided by referring to Mathews v. Eldridge. ${ }^{57}$ The Mathews test determines the sufficiency of a procedure by examining three criteria: (1) the private interest affected; (2) the risk of an erroneous deprivation of the interest through the current procedure and the probable value of additional procedural safeguards; and (3) the nature of the government's imterest. ${ }^{58}$

The weight assigned to the first criterion-the affected private interest-will vary depending upon the nature of the case. A marginal economic effect on the person against whoin an admimistrative rule is sought to be enforced probably does not constitute a sufficient interest to surmount the congressionally established policy against enforceinent review. But when a party alleges that enforcement of a rule would seriously impair the economic health of, or destroy, a multi-million dollar industry, a judge will have difficulty denying the objector the opportunity to assert in enforcenent proceedings that the rule is invalid. 59 With respect to the nature of the private imterests affected, a comparison of Yakus with cases that inay arise under current environmental statutes must consider the different enforcement programs involved.

\footnotetext{
54. 600 F.2d at 912 .

55. The recommendation appears at $41 \mathrm{Fed}$. Reg. 56,768 (1976).

56. 600 F.2d at 913 (citing 434 U.S. at 290 (Powell, J., concurring)). The problems the courts face in deciding which administrative pronouncements are incontestable under the new statutes creating such incontestability are similar to the problems of deciding which administrative pronouncements are "orders" reviewable in the courts of appeal under statutory provisions such as the Hobbs Act, and which pronouncenents are reviewable only in the federal district courts. See, eg., Harrison v. PPG Indus., 446 U.S. 578 (1980); Sima Products Corp. v. McLucas, 612 F.2d 309 (7th Cir.), cert. denied, 446 U.S. 908 (1980). United Gas Pipe Lime Co. v. FPC, 181 F.2d 796 (D.C. Cir.), cert. denied, 340 U.S. 827 (1950).

57. 424 U.S. 319 (1976). Mathews involved a challenge to the Social Security Adninistration's procedure of terminating disability benefits without a pre-termmation evidentiary hearing. The Supreine Court enunciated a three-part balancing test for analyzing due process cases, $i d$, at 335 , and held that the post-termination hearing provided by the agency satisfied due process, $i d$. at
} 349.

58. Id. at 334-35.

59. See, e.g., United States v. Nova Scotia Prods. Corp., 568 F.2d 240 (2d Cir. 1977). 
Yakus involved criminal penalties against individuals who violated the regulations. Although cases arising under the environmental statutes conceivably could produce contempt citations, a conventional criminal prosecution will not normally result from an enforcement proceeding. Because personal liberty is one of the most highly valued interests that the Supreme Court recognizes in applying the Mathews v. Eldridge test, ${ }^{60}$ a court might uphold the incontestability provisions of the environmental statutes because of the absence of criminal penalties. Whether such a distinction would be decisive remains to be seen, of course, but it is certainly a factor to consider.

The risk that foreclosing review of rules beyond a limited time will erroneously deprive the affected party of its interest-the second $\mathrm{Ma}$ thews criterion-is great. Several obstacles may prevent an affected party from participating in the limited pre-enforcennent review and thus cause it to have no opportunity to challenge the regulation. For example, persons may not liave notice of the regulation when pre-enforceinent review is available. As Justice Powell noted in his Adamo concurrence, typically the only notice of the promulgation of a regulation is publication in the Federal Register. ${ }^{61}$ Although large corporations may have the resources necessary to monitor the register, individuals and small firms may not be able to afford this expense and may not even be aware of or liave access to the register. ${ }^{62}$ Even if a person has notice of a regulation, he inay not become aware of a defect in the regulation, or of how the regulation affects him, until after the time for pre-enforcement review expires. ${ }^{63}$ Professor David Currie, discussing the Clean Air Act, las pointed out that the statute "even appears to make invalidity unavailable as a defense [in an enforcement proceeding] to persons who went into the affected business, inoved into the affected area, or indeed were born after the thirty-day or ninety-day period." 64

The third criterion in the Mathews $v$. Eldridge test is the nature of the government interest. The distinction between the provisions of the Emergency Price Control Act upheld in Yakus and the current incontestability clauses contained in environmental statutes is most evident with respect to this criterion. Congress's concern that its environinental

60. 424 U.S. at $341 ; f f . \mathrm{Ng}$ Fung Ho v. White, 259 U.S. 276 (1922).

61. 434 U.S. at 289 (Powell, J, concurring).

62. Id. at 290 (Powell, J., concurring); Chrysler Corp. v. EPA, 600 F.2d 904, 912-13 (D.C. Cir. 1979).

63. See, e.g., Chrysler Corp. v. EPA, 600 F.2d 904, 913 n.78 (D.C. Cir. 1979); Independent Cosmetic Mfrs. v. Department of HEW, 574 F.2d 553 (D.C. Cir. 1978), cert. denied, 439 U.S. 893 (1980).

64. Currie, supra note 3, at 1258. 
programs not be paralyzed by a plethora of law suits and legal maneuvers is surely a legitimate one. ${ }^{65}$ But as Justice Powell indicated, "As important as environmental concerns are to the country, they are not comparable-in terms of an emergency justifying the shortcutting of normal due process rights - to the need for national mobilization in wartime of economic as well as military activity." 66

The less coinpelling government interest in the environmental statutes, coupled with the great danger of foreclosing judicial review altogether with barriers to pre-enforcement review, suggests that the constitutionality of the current review-limiting statutes is problematical. ${ }^{67}$ This situation suggests the need to examine alternatives to the total foreclosure of challenges to the validity of regulations beyond the statutory review period.

\section{Two Proposals for Softening the Harsh and Pre- EMPTIVE EFFECTS OF THE INCONTESTABILITY CLAUSES}

Should Congress continue to make administrative rules incontestable in enforcenent proceedings when there has been a limited period made available for pre-enforceinent review, two devices may take some of the sting out of the injustice that the application of such foreclosure

65. See Granite City Steel Co. v. EPA, 501 F.2d 925, 926 (7th Cir. 1974) ("The time limit is not arbitrary but is designed to get issues resolved promptly and thereby prevent delay in cleaning the air").

66. Adamo Wrecking Co. v. United States, 434 U.S. 275, 290 (1978) (Powell, J., concurring).

67. The danger of foreclosing all opportunity for review is heightened by the fact that a court may prevent a petitioner from taking part in a pre-enforcement challenge to the validity of a regulation by finding that the petitioner fails to satisfy requirements of standing and ripeness. Decisions using these doctrines to limit the availability of pre-enforcement review risk shipwrecking an innocent party between the Scylla of standing and the Charybdis of incontestability. See Independent Cosmetic Mfrs. v. Department of HEW, 574 F.2d 553 (D.C. Cir. 1978), cert. denied, 439 U.S. 893 (1980).

Cases struggling with the subtleties of standing and ripeness issues include Council of Forest Indus. v. ICC, 570 F.2d 1056 (D.C. Cir. 1978), and Bethlehem Steel Corp. v. EPA, 536 F.2d 156 (7th Cir. 1976). Some courts, in deterınining the availability of pre-enforcement review, are influenced by whether the party seeking review failed to participate in the administrative processes leading to the formulation of the rule. See, e.g., First Nat'l Bank v. Board of Governors of the Fed. Reserve Sys., 509 F.2d 1004 (8th Cir. 1975); Application of Hawaiian Elec. Co., 56 Hawaii 260, 264, 535 P.2d 1102, 1105 (1975) ("It is not enough that a person has been 'aggrieved' by agency action. He must also have contested the issue before the agency"); Annot., 36 A.L.R. FED. 349, 353-59 (1978). One who fails to participate in the proceedings for the formulation of a rule may be required, as a condition to judicial review, to first petition the agency to amend, modify, or repeal. See Nader v. Nuclear Regulatory Coinm'n, 513 F.2d 1045, 1049-51 (D.C. Cir. 1975). The scope of review of the agency action in refusing relief is then goverued by the "arbitrary and capricious" test of 5 U.S.C. $\$ 706(2)$ (A) (1976). 513 F.2d at 105 l. On the other hand, cases subject to the formal hearing procedures of 5 U.S.C. $\$ \S 556,557$ (1976), will entitle the petitioner to the allegedly inore exacting "substantial evidence" test on judicial review. Aircraft Owners \& Pilots Ass'n v. FAA, 600 F.2d 965, 969 (D.C. Cir. 1979). 
policies can generate. These devices are: (1) authorizing agencies to grant waivers from their rules; and (2) allowing judicial review of petitions to amend or repeal rules. Neither device is new or original. The Supreme Court has sanctioned the waiver approach, ${ }^{68}$ and Congress has specifically provided for waivers in the recent Magnuson-Moss Warranty-Federal Trade Commission Improvement Act. ${ }^{69}$ The Court of Appeals for the District of Columbia Circuit has, in a number of cases, indicated that agencies inust seriously consider petitions to amend or repeal its rules and that refusals to amend or repeal are subject to judicial review. ${ }^{70}$

\section{A. The Waiver Approach .}

In United States v. Storer Broadcasting Co. ${ }^{71}$ the Supreme Court took a surprisingly liberal approach to the power of an agency to waive compliance with its rules. The rules at issue were Federal Communications Commission regulations disqualifying persons having an ownership interest in five broadcasting facilities from receiving additional permits. ${ }^{72}$ The Court rejected Storer's argument that it was entitled to a trial-like hearing at which its inultiple-ownership status would be only one of the considerations in deciding whether to grant the permit. The agency's regulations allowing petitions for waiver of the rules ${ }^{73}$ were sufficient to allow the applicant to argue that it should be granted an application despite the multiple ownership. ${ }^{74}$

The Storer Broadcasting opinion's assurances that the waiver regulation would satisfy Storer's rights to a "full hearing" under the stat-

68. United States v. Storer Broadcasting Co., 351 U.S. 192, 205 (1956).

69. 15 U.S.C. $§ 57 \mathrm{a}(\mathrm{g})(1)$, (2) (1976). These subsections provide:

(g)(1) Any person to whom a rule under subseetion (a)(1)(B) of this section applies may petition the Commission for an exemption from such rule.

(2) If, on its own motion or on the basis of a petition under paragraph (1), the Commission finds that the application of a rule prescribed under subsection (a)(1)(B) of this section to any person or class [of] persons is not necessary to prevent the unfair or deceptive act or practice to which the rule relates, the Commission may exempt such person or class from all or part of such rule. Section 553 of title 5 shall apply to action under this Id. paragraph.

70. See Monsanto Co. v. Kennedy, 613 F.2d 947, 954 (D.C. Cir. 1979); Geller v. FCC, 610 F.2d 973, $978-79$ (D.C. Cir. 1979); ASG Indus. v. Consumer Prod. Safety Comm'n, 593 F.2d 1323, 1330 (D.C. Cir.), cert. denied, 444 U.S. 864 (1979); Lammators Safety Glass Ass'n v. Consumer Prod. Safety Comm'n, 578 F.2d 406, 411 (D.C. Cir. 1978); Investment Co. Inst. v. Board of Goveruors of the Fed. Reserve Sys., 551 F.2d 1270, 1281 (D.C. Cir. 1977). At least one eminent scholar has previously eudorsed this procedure. See Auerbach, supra note 3, at 16.

71. 351 U.S. 192 (1956).

72. Id. at 193, 194 n.I. See 47 C.F.R. $\$ \$ 3.240, .35, .636$ (1953).

73. 47 C.F.R. $\$ \S 1.361$ (c), 1.702 (1953), reprinted in United States v. Storer Broadcasting Co., 35I U.S. 192, 201 n.10 (1956).

74. 351 U.S. at 205. 
ute $^{75}$ indicates that applications for amendment, repeal, or waiver should not be taken lightly, and that the agency should carefully consider the arguments, grounds, and circumstances advanced in support of the waiver. ${ }^{76}$ The waiver provision is a trade-off for the agency's ability to avoid a trial-type hearing by having a bright-line rule that disqualifies an applicant on the basis of a factor that would almost always disqualify him even if there was such a hearing. A party may be affected by the rule in a way not contemplated by the drafters, and the agency is obliged to provide a procedure through which that party inay seek to be excused froin compliance.

A systein of waivers from regulations, however, entails two inajor defects. First, the objectives of the regulatory program nay be impaired by a dispensation granted pursuant to views through lenses that show only the needs of the waiver applicant and that may not reveal collateral consequences that might undermine the regulatory scheme. Experience at the local government level with zoning variances illustrates the subversive and uneven results that such a system can produce. ${ }^{77}$ The second defect is based on considerations of fairness. Under a waiver procedure, it is possible for a shrewd waiver apphicant to acquire a ruinous competitive advantage by receiving a dispensation in a proceeding at which his economic adversaries had no real opportuinty to appear. For these reasons, the waiver approach appears to have only himited utility. ${ }^{78}$

\section{B. More Intensive Consideration to Applications for Amendment, Modification, or Repeal of Rules.}

A rule allowing petitions to be submitted to the agency to amend, modify, or repeal regulations and providing judicial review of the agency's disposition of a petition would provide an avenue of review to those otherwise foreclosed by incontestability clauses and would avoid the two major defects of a waiver system. If an objector inust petition for unodification rather than seek a waiver, the agency will be encouraged to consider fully all policies relevant to the modification or

75. Id.

76. Id. at 202-05.

77. See Dukeminier \& Stapleton, The Zoning Board of Adjustment: A Case Study in Misrule, 50 Ky. LJ. 273, 324-39 (1962); Newbern, Zoning Flexibility: Bored of Adjustment?, 30 ARK. L. Rev. 491, 510-11 (1977); Shapiro, The Zoning Variance Power-Constructive in Theory, Destructive in Practice, 29 MD. L. Rev. 3 (1969).

78. An additional problem is presented by the functional equivalence of a rules waiver to a license; both grant permission to engage in an activity otherwise prohibited. All of the subtle due process complexities with which the courts have dealt in attempting to ensure fairness to license applicants and their competitors are, sooner or later, bound to surface under such a system. 
repeal issue. When only an application for a waiver is pending, however, the agency may give undue weight to the needs of the individual applicant. Whereas granting waivers can cause such uneven application of the rule that the original policy goals may become seriously subverted, positive response to a petition for amendment, inodification, or repeal of a rule apphes to all covered by the rule. The unfair advantage granted to a successful waiver apphicant is also thereby avoided. ${ }^{79}$ The facts of Nova Scotia Food Products Corp. ${ }^{80}$ inay be used to illustrate the difference between the two procedures. Had Nova Scotia apphed for and been granted a waiver from the Food and Drug Administration's fish-smoking rule, it would have had a distinct competitive advantage over all other processors of whitefish who, in the absence of waivers, would still be subject to the rule. On the other hand, had Nova Scotia petitioned for and been granted an amendment or modification of the rule that recognized the particular problems of processing whitefish, all whitefish processors would receive the same advantage.

In several cases in which it has affirmed dismissals of suits challengimg agency regulations outside the limited pre-enforcennent review period, the Court of Appeals for the District of Columbia Circuit has indicated the availability of a petition to amend directed to the agency as a means of obtaining review of the regulation. ${ }^{81}$ For example, in Laminated Safety Glass Association v. Consumer Product Safety Commission $^{82}$ the court endorsed the petition-to-amend procedure as a way of accommodating the discovery of new information by the petitioner after the end of the sixty-day review period. ${ }^{83}$ In Investment Company Institute v. Board of Governors of the Federal Reserve System ${ }^{84}$ the court described what would constitute the administrative record for purposes of reviewing an agency's denial of a petition to amend, ${ }^{85}$ and stated

79. When the amendment has the effect of providing a waiver to a particular person or class, the distinction between an amendment and a waiver may appear more formal than real. But any other person or group that can fit itself imto the language of the modification enjoys the benefits of the amendment without the need for special application.

80. 568 F.2d 240 (2d Cir. 1977). See text accompanying notes 34-36 supra.

81. See, e.g., City of Rochester v. Bond, 603 F.2d 927, 931 (D.C. Cir. 1979); Laminated Safety Glass Ass'n v. Consumer Prod. Safety Comm'n, 578 F.2d 406, 411 (D.C. Cir. 1978); Investment Co. Inst. v. Board of Governors of the Fed. Reserve Sys., 551 F.2d 1270 (D.C. Cir. 1977); $c f$. Nader v. Nuclear Regulatory Comm'n, 513 F.2d 1045, 1051 (D.C. Cir. 1975) (Nader had not participated in the review of the regulations before their enactment and thus the denial of his petition to amend was properly appealable to the court of appeals).

82. 578 F.2d 406 (D.C. Cir. 1978).

83. Id. at 411 .

84. 551 F.2d 1270 (D.C. Cir. 1977).

85. Judge McGowan stated: "The admmistrative record for review would imclude the inforunation and affidavits submitted to the agency by the aggrieved party, the record of any hearings 
that the proper standard of review was the "arbitrary, capricious, an abuse of discretion, or otherwise not in accordance with law" standard. ${ }^{86}$

Dean Auerbach of the University of Minnesota and Professor Wilhams of the University of Colorado have called for the petition to amend or repeal, with judicial review and remand to the agency of cases involving unsatisfactory responses, as the wisest and most acceptable means of dealing with situations in which a literal application of rules produces unwarranted results. ${ }^{87}$

Judicial review of the considerations nroving the agency to deny a requested amendment or repeal of a rule is a fairer and more efficient method of correcting a perceived injustice than the waiver approach. Agency response to an application for amendment or repeal will more likely consider collateral responsibilities within the agency's concern than will the response to a waiver petition, when the agency focus tends to confine itself to the predicament of the applicant. Moreover, a judicial disapproval on appeal of the administrative denial of the request ordimarily results in a remand to the agency, whereas in deciding the propriety of a waiver denial, some judges may be tempted to deal with the merits, thereby undercutting the agency's responsibility to deal with collateral considerations that frequently are not central to the waiver request. ${ }^{88}$

It was this concern for the integrity of the administrative process that prompted Justice Frankfurter, writmg for the Court in Addison v. Holly Hill Food Co. ${ }^{89}$ to remand to the agency, for reformulation, an ultra vires rule. Although the decision created a risk of retroactive lawmaking by the agency, Justice Frankfurter reasoned that to invahidate or remterpret the rule without agency participation would be a usurpation by the Court of a responsibility that Congress liad confided to the agency. 90

\section{CONCLUSION}

The use of rule-incontestability clauses, which courts sometimes imply in pattern 4 statutes ${ }^{91}$ and which Congress explicitly provides in

on the matter, and the Board's response (which might incorporate by reference the record of the origimal rulemaking proceeding)." Id. at 1281 .

86. Id. (quoting 5 U.S.C. $\$ 706(2)$ (A) (1976)).

87. See Auerbach, supra note 3, at 16, 61-68; Williams, "Hybrid Rulemaking" under the Administrative Procedure Act, 42 U. CH1. L. REv. 401, 424-25 (1975).

88. See Spence v. B \& O Ry., 360 F.2d 887 (7th Cir.), cert. denied, 385 U.S. 946 (1966).

89. 322 U.S. 607 (1944).

90. Id. at 619-22.

91. See text accompanying notes 23-37 supra. 
pattern 5 statutes, ${ }^{92}$ invites a constitutional confrontation over the continued validity of the controversial Yakus decision. Recent cases have avoided this confrontation only by characterizing the administrative pronouncements under consideration as not within the class of rules that Congress intended to be incontestable. ${ }^{93}$

The congressional desire for certainty and predictability concerning the validity of agency regulations may be accommodated with the goal of fairness to those affected by the regulations by permitting cliallenges to rules in enforceinent proceedings only if the respondent can show that he is inaterially aggrieved by the alleged defect. As in cases dealing with the question of the propriety of a stay, 94 or the question whether the traditional exhaustion requireinent ${ }^{95}$ should be dispensed with, a court gauging the intensity of the aggrievement would consider a number of relevant factors, including the relative impairment of governmental objectives. The respondent would obviously have a lieavy burden to carry.

Whether or not agency regulations are incontestable in enforcement proceedimgs, aggrieved persons should be permitted to petition the agency to amend, modify, or repeal regulations and to appeal the agency's denial of the petition to the district court unless a statute provides for review in another court. ${ }^{96}$ A petition-to-amend procedure avoids the problems of the waiver approach. If the aggrieved party is required to seek an amendment or repeal, rather than a waiver, and if the agency follows notice and comment procedures in making its determination, the danger that the administrative program may be impaired

\footnotetext{
92. See text accompanying notes 38-67 supra.

93. Adamo Wrecking Co. v. United States, 434 U.S. 275 (1978); Chrysler Corp. v. EPA, 600 F.2d 904 (D.C. Cir. 1979).

94. Scripps-Howard Radio, Inc. v. FCC, 316 U.S. 4 (1942); Virgmia Petroleum Jobbers Ass'n v. FPC, 259 F.2d 921 (D.C. Cir. 1958).

95. See note 37 supra.

96. Agencies that exercise rulemaking authority should adopt formal procedures for disposing of petitions to amend or repeal rules. The adoption of such procedures would not alter the scope of review of the agency's decision; rather, it would assist the agency in appraising the facts and circumstances involved in the particular apphications of the rule to which the petitioners object. The adoption of procedures for disposing of amendment petitions would also assist the agency in refining or amending the rule so as to avoid anomalous applications without impairing the adminstrative objectives of the rule. Procedures for disposing of amendinent or repeal petitions should include provisions for notice-and-comment procedures equivalent to those provided for under section four of the Administrative Procedure Act, 5 U.S.C. $\$ 553$ (1976). This would provide soine assurance that the agency would be advised of all the consequences of an amendinent or repeal. The person petitioning for the amendment or repeal will typically submit data and arguments relevant only to his own situation thus creating a danger of adverse consequences that were unforeseen at the time the petition was considered. The notice-and-comment procedures would ensure the receipt of information and arguments representing a nuinber of viewpoints that might not otherwise reach the attention of the agency.
} 
in some unforeseen manner or that the petitioner will obtain an unfair advantage over its competitors is greatly reduced. The availability of appeal from the dernal of an amendment petition permits judicial relief when application of the rule would be contrary to the Constitution or to congressionally-expressed pohicies or objectives. 


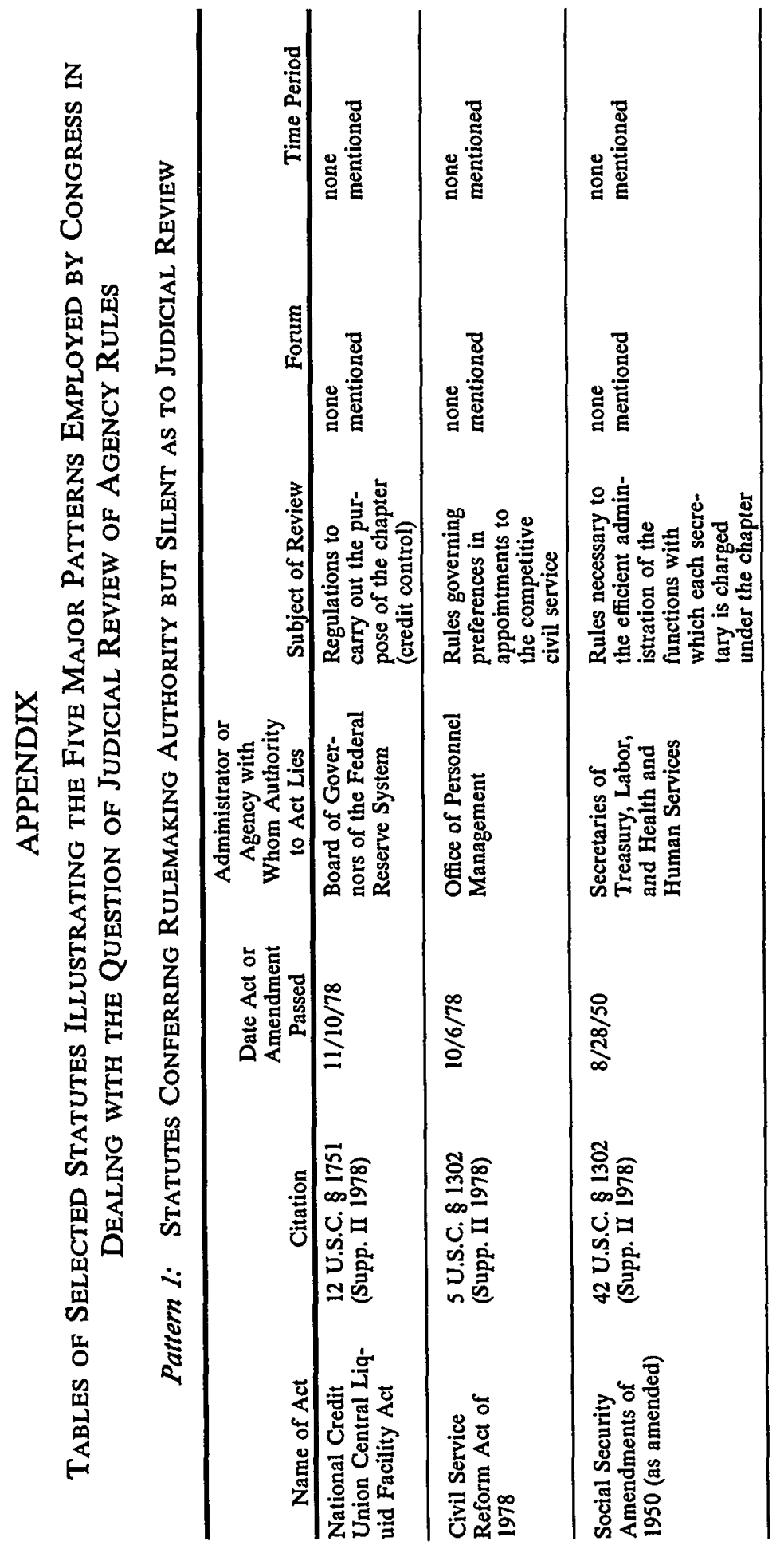




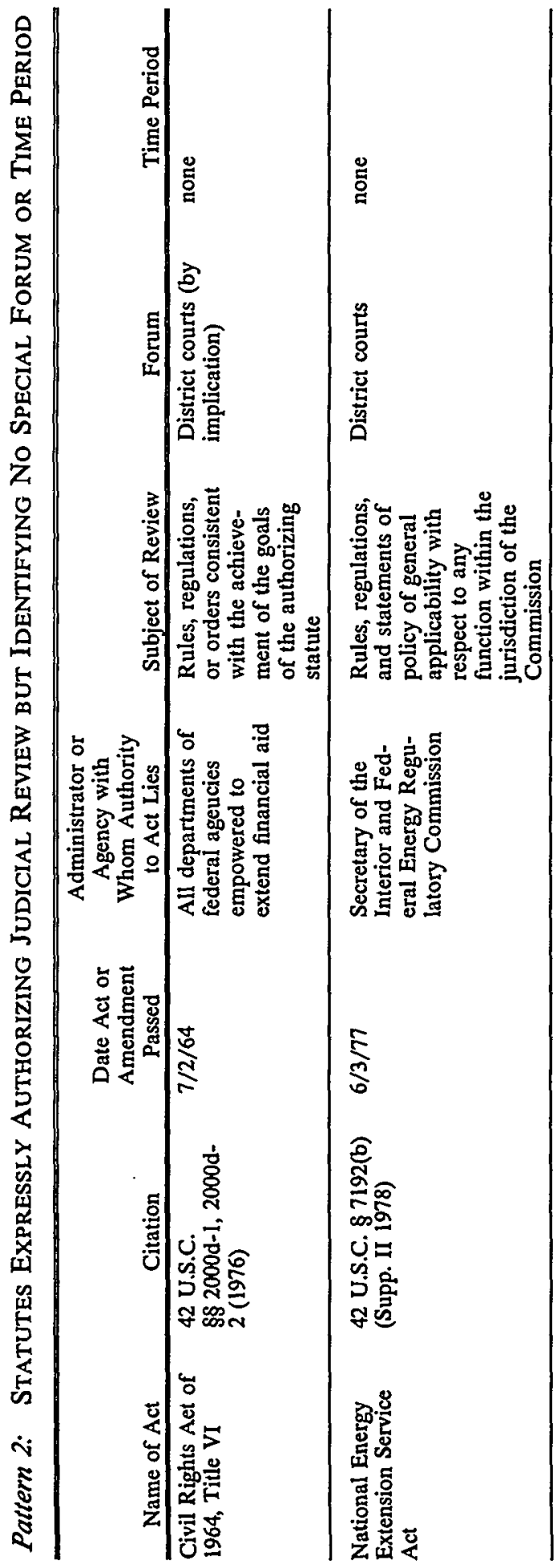




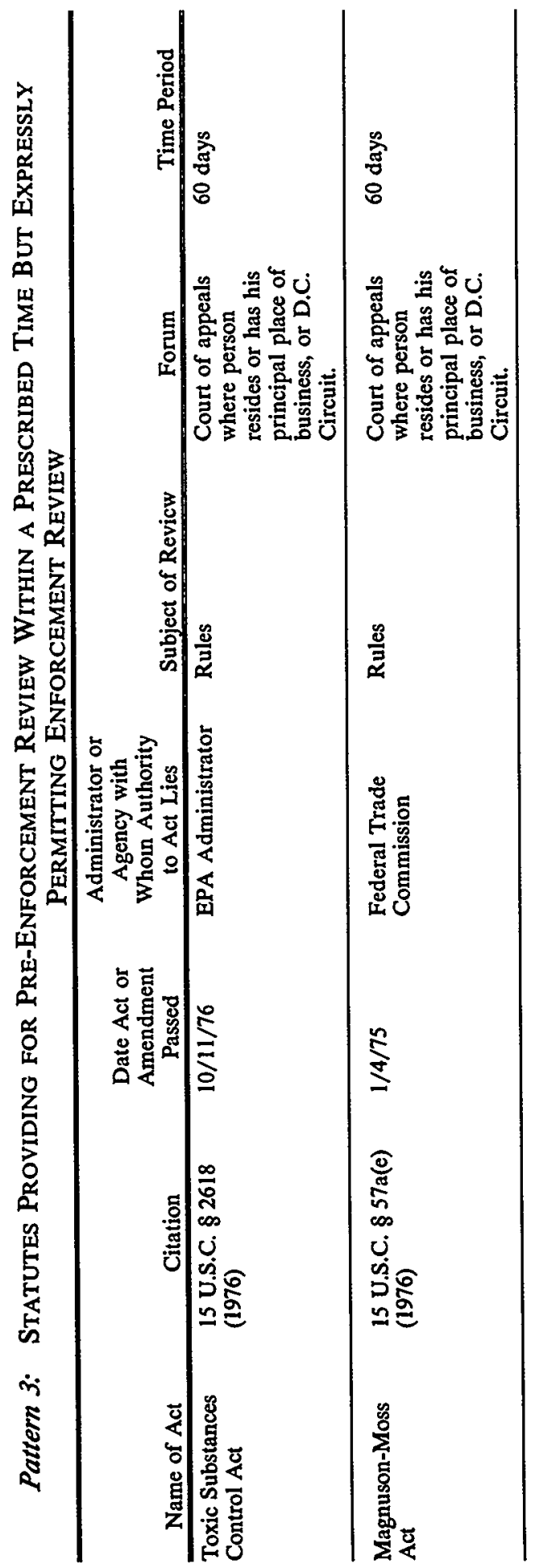




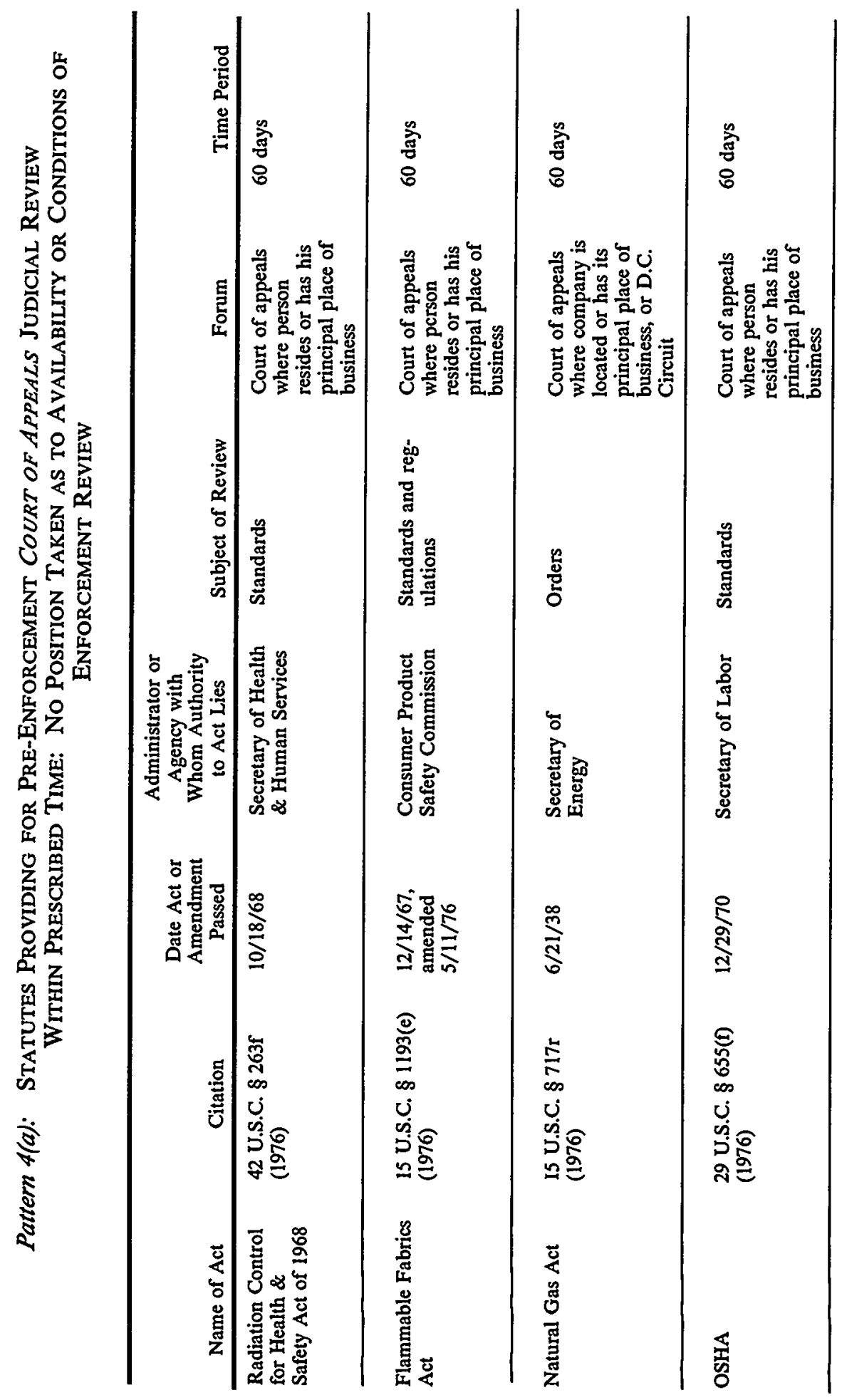




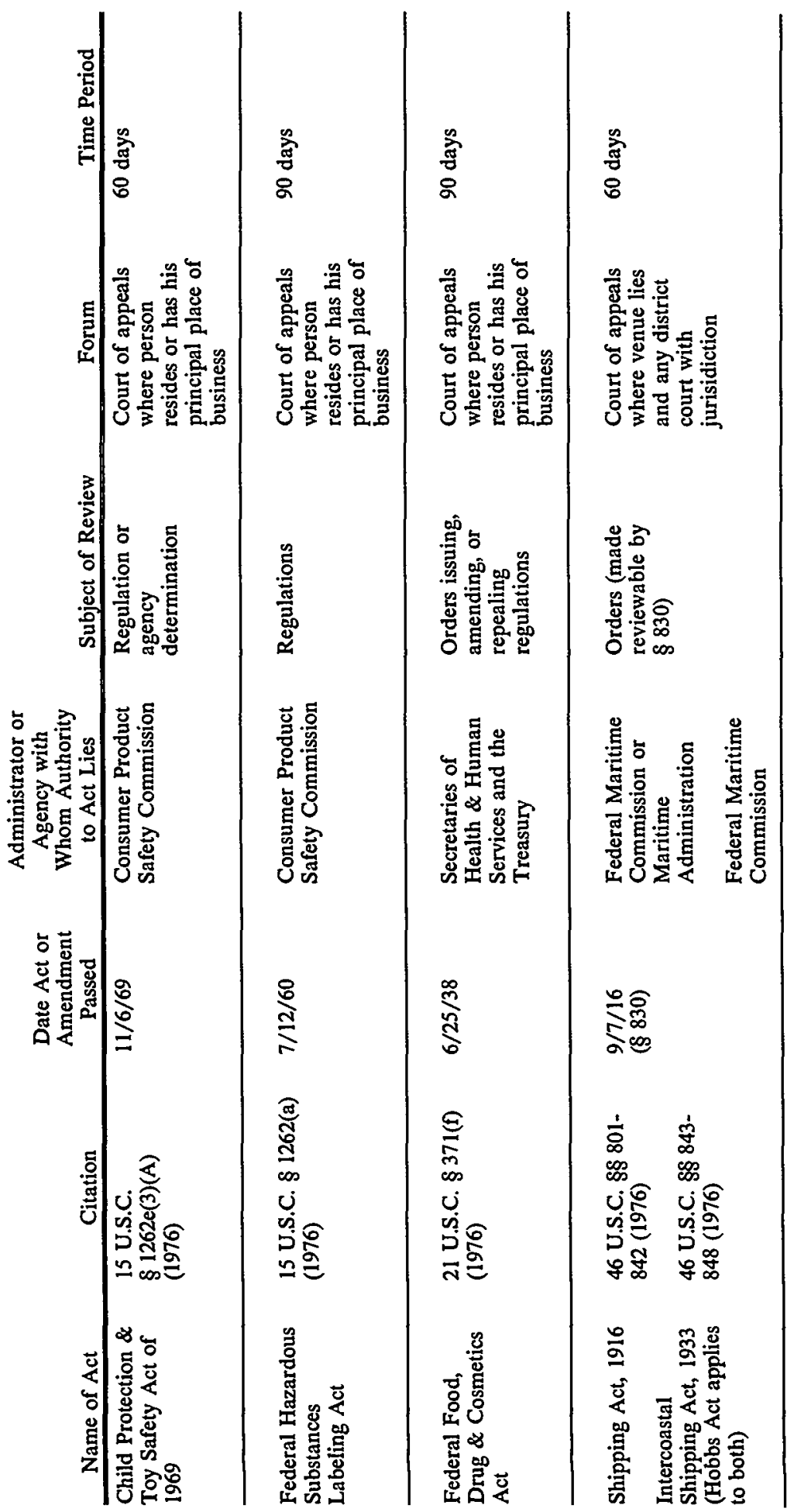




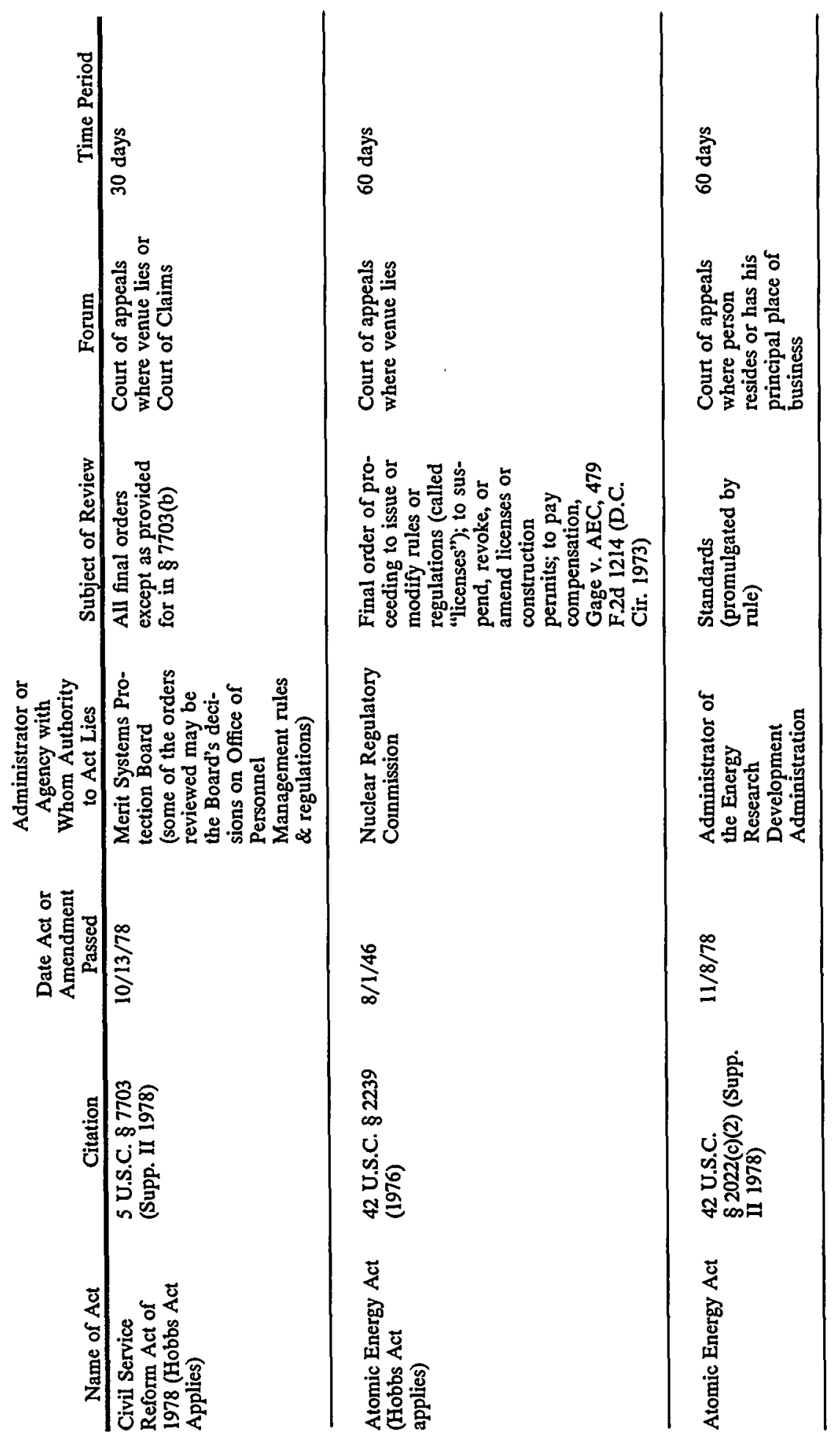




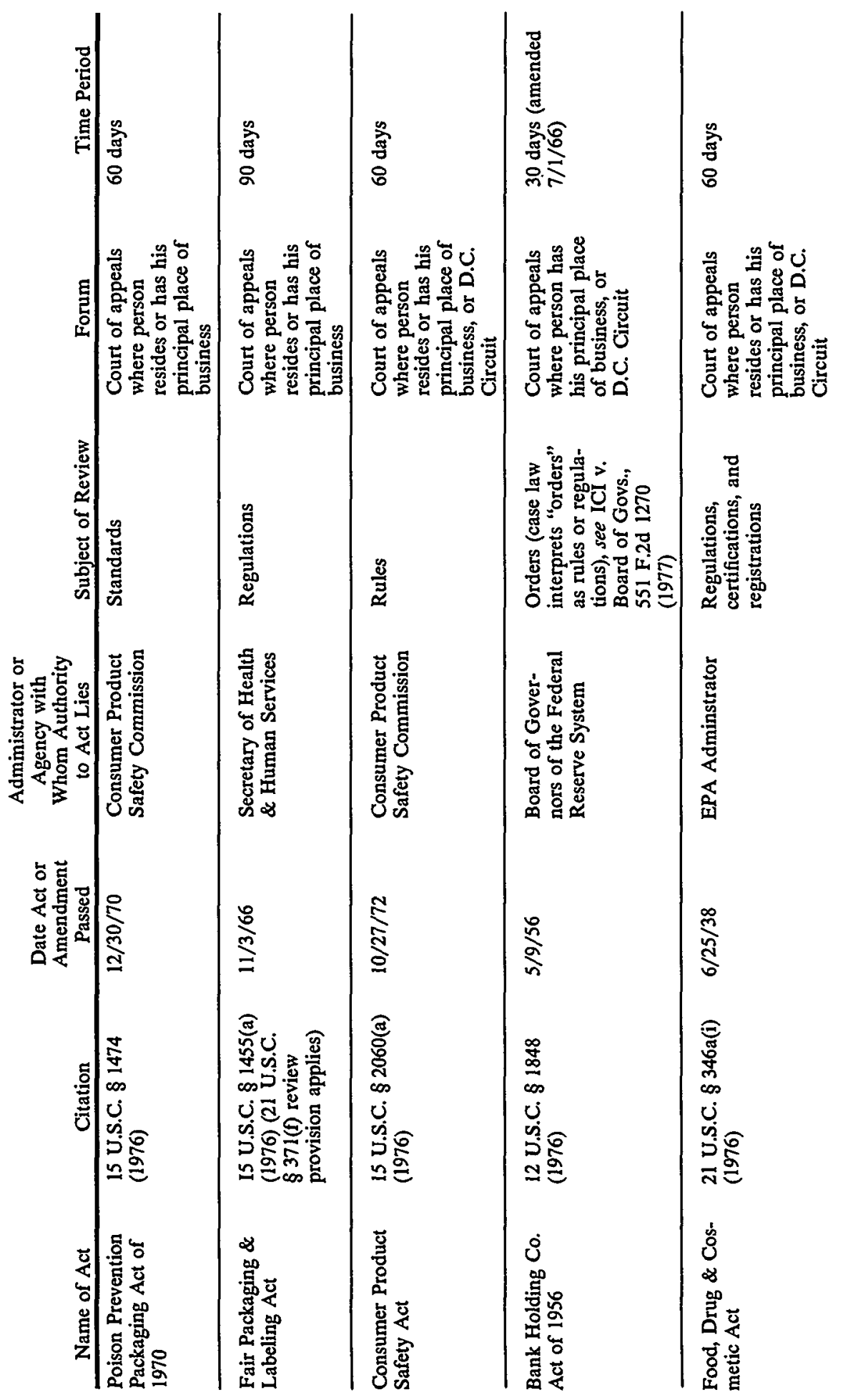




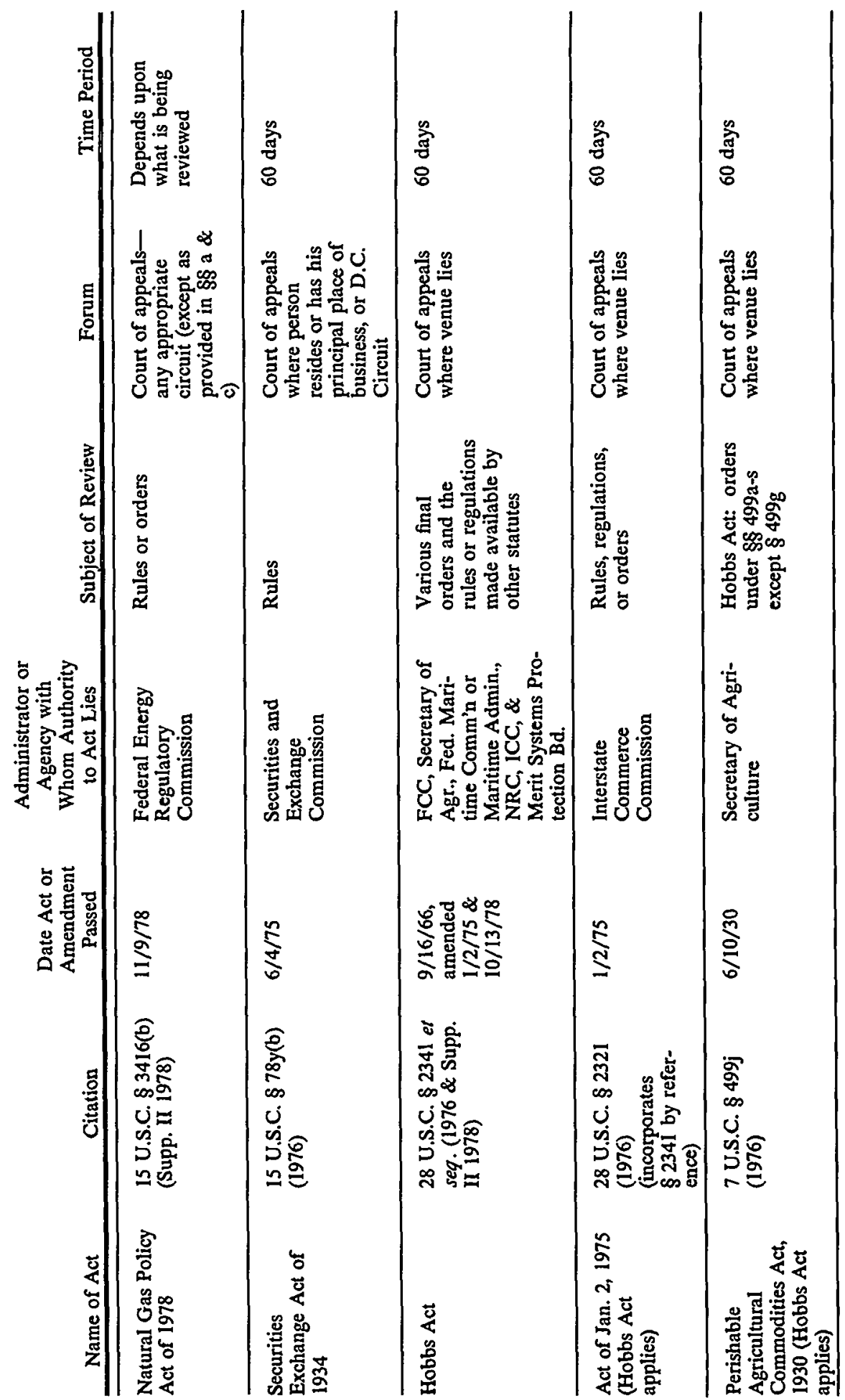




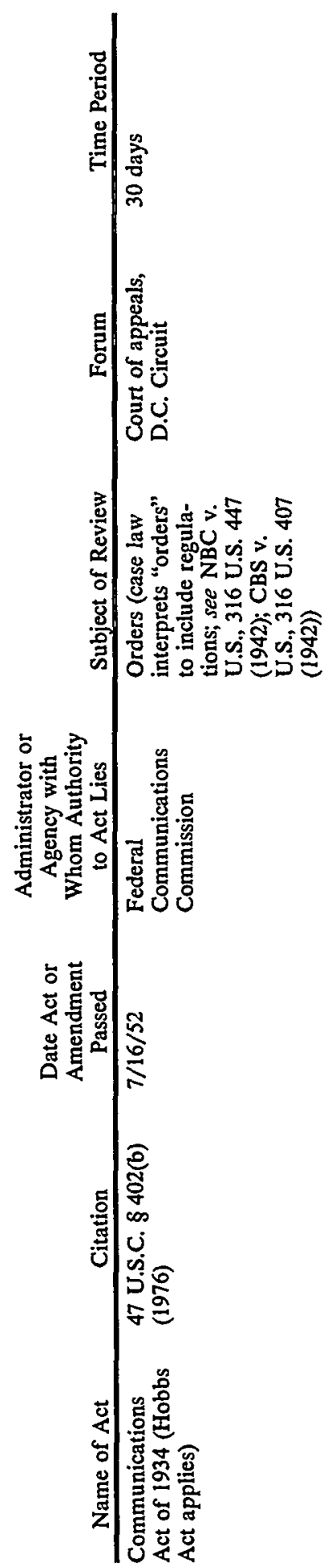




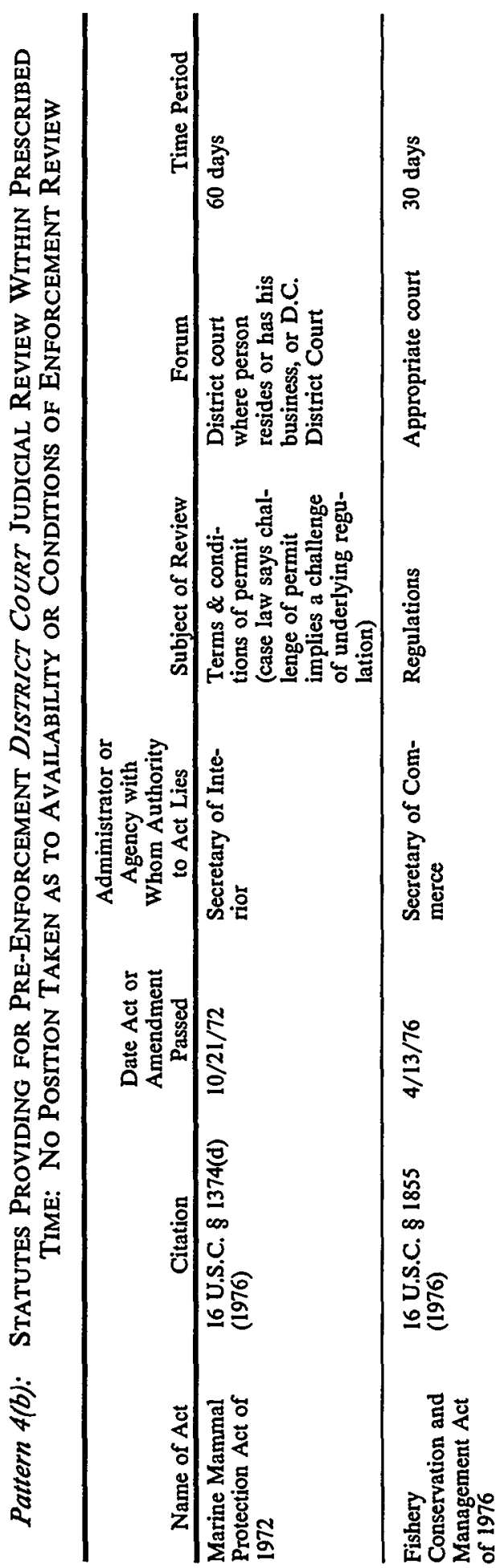




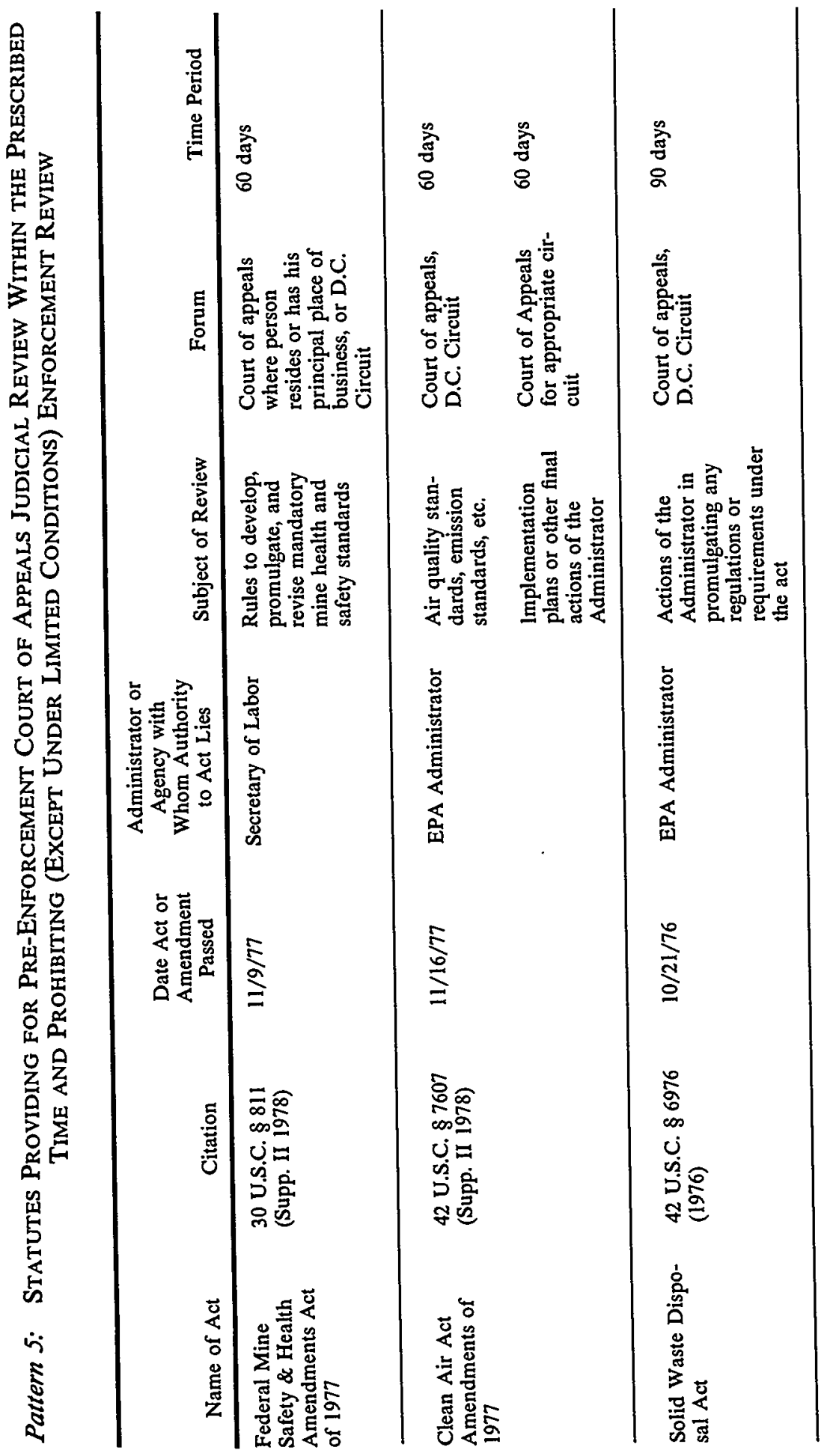




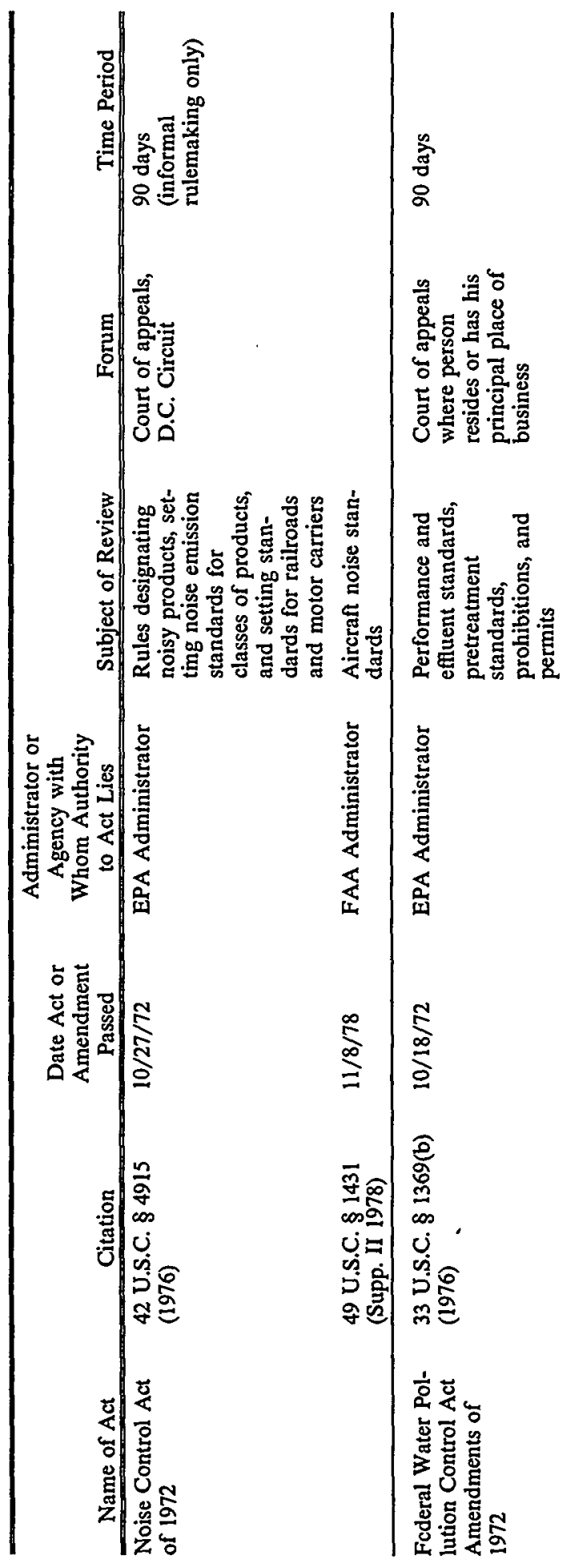

